\title{
Kajian Yuridis Undang-Undang Nomor 35 Tahun 2014 Tentang Perlindungan Anak dalam Perspektif Pendidikan
}

\author{
Zaini Bidaya', Muh. Rangga² \\ ${ }^{1}$ Pendidikan Pancasila dan Kewarganegaraan, Universitas Muhammadiyah Mataram, Email: zainibidaya@gmail.com \\ ${ }^{2}$ Pendidikan Pancasila dan Kewarganegaraan, Universitas Muhammadiyah Mataram, Email: rangga.elreal06@gmail.com
}

\begin{tabular}{l} 
INFO ARTIKEL \\
Riwayat Artikel: \\
Diterima: $\quad$ 16-Februari- \\
2019 \\
Disetujui: 25-Maret-2019 \\
\hline
\end{tabular}

Kata Kunci:

yuridis

undang-undang

perlindungan

anak

pendidikan

\begin{abstract}
ABSTRAK
Abstrak: Undang-undang Nomor 35 Tahun 2014 tentang perlindungan anak merupakan salah satu produk kebijakan dalam melindungi anak dalam berbagai persolan dalam kehidupan keluarga, pendidikan, lingkungan dan Negara, dalam mengimplementasikan nilai undang-undang tersebut masih terjadi kendala baik secara yuridis maupun legislasi. Tujuan dalam penelitian ini menjelaskan kajian yuridis Undang-undang Nomor 35 tahun 2014 tentang perlindungan anak dalam perspektif pendidikan. Jenis penelitian adalah penelitian kualitatif dengan pendekatan deskriptif, tehnik penentuan subyek menggunkan purposive sampling dan snowball sampling, jenis data yaitu data kualitatif, sumber data, metode pengumpulan data adalah observasi, wawancara dan dokumentasi sedangkan teknik analisis data yaitu, reduksi, penyajian, dan menarik kesimpulan. Hasil penelitian menunjukkan bahwa adanya undang-undang nomor 35 tahun 2014 dapat menjadi pedoman sekolah dalam melindungi peserta didik sebagai subyek hukum. Terkait dengan hal tersebut bagi guru sudah tidak bisa lagi mendidik, mengajar, membimbing dan mendisiplinkan peserta didik dengan cara menberikan hukuman fisik maupun psikis terhadap peserta didik karna ini mengandung kekerasan baik fisik maupun mental yang bisa mengganggu perkembangan peserta didik dalam menggembangkan pengetahuan, bakat serta kreatifitas yang dimiliki peserta didik.
\end{abstract}

\begin{abstract}
Law No. 35 of 2014 concerning child protection is one of the policy products in protecting children in various problems in family life, education, environment and the State, in implementing the value of the law there are still obstacles both in juridical and legislative terms. The purpose of this study explains the juridical study of Law No. 35 of 2014 concerning child protection in an educational perspective. This type of research is a qualitative research with a descriptive approach, subject determination techniques using purposive sampling and snowball sampling, the type of data is qualitative data, data sources, data collection methods are observation, interviews and documentation while the data analysis techniques are, reduction, presentation, and drawing conclusions. The results showed that the existence of law number 35 of 2014 can be a school guide in protecting students as legal subjects. Related to this, teachers are no longer able to educate, teach, guide and discipline students by giving physical and psychological punishment to students because this contains both physical and mental violence that can interfere with the development of students in developing knowledge, talent and creativity owned by students.
\end{abstract}

\section{A. LATAR BELAKANG}

Pulau Lombok merupakan salah satu pulau di wilayah Provinsi Nusa Tenggara Barat yang mayoritas penduduknya memeluk agama Islam. Nuansa religi yang begitu kental dan deretan-deretan bangunan masjid yang menghiasi pulau ini membuat pulau dikenal sebagai pulau seribu masjid. Saat ini Pulau Lombok sudah dikenal oleh masyarakat dunia sebagai salah satu tujuan wisata, karena memiliki potensi alam yang indah dengan pesona alam bahari, pantai-pantainya yang berpasir putih, pemandangan alam bawah laut serta pemandangan-pemandangan indah di daratan yang membuat daerah ini banyak dikunjungi para wisatawan.
Selain pesona alam yang dimiliki, pulau lombok juga banyak menyimpan warisan-warisan budaya lokal seperti musik tradisional, seni tari, dan lain-lain sebagaimana yang dimiliki oleh daerah lain di Indonesia.

Salah satu objek wisata yang terkenal di Pulau Lombok adalah Pantai Batu Layar. Sebelum menjadi objek wisata, puluhan tahun lalu kawasan pantai Batu Layar ditumbuhi semak belukar, tumbuhan liar, dan sebagai tempat pengembala ternak, seperti kambing dan sapi. Seiring dengan perkembangan zaman, sampai saat ini wilayah Batu Layar sudah mulai berbenah dan menjadi objek wisata yang sering dikunjungi oleh para wisatawan baik domestik maupun mancanegara. 
Pantai Batu Layar memiliki pemandangan bawah lautnya sangat indah, dengan hamparan pasir putih yang menarik wisatawan untuk duduk di atasnya dan menghirup udara segar dengan menikmati pemandangan air laut yang berwarna biru gradasi hijau serta menikmati indahnya matahari terbenam. Wisatawan bisa melakukan snorkling sepuasnya karena ombaknya tidak terlalu besar.

Dari pantai Melase yang termasuk kawasan pantai di Desa Batu Layar dengan berjalan kaki terdapat makam seorang ulamayaitu Makam Batu Layar. Makam ini ramai di kunjungi pada saat "Lebaran Ketupat" yang merupakan lebaran bagi orang yang berpuasa 1 minggu setelah lebaran Idul Fitri. Tidak jauh dari makam Batu Layar, para wisatawan dapat menjumpai Pura Batu Bolong yang dibangun di atas karang yang terletak di tepi pantai.

Dengan berbagai macam pesona alam yang ada di Desa Batu Layar ini dapat memberikan dampak yang sangat luas bagi masyarakat. Kehidupan masyarakat Desa Batu Layar bergantung pada hasil kekayaan laut, karena hampir sebagian masyarakat-nya hidup sebagai nelayan, sehingga dalam membiayai kebutuhan hidup sehari-harinya, mereka mengandalkan hasil perpetanian dan penjualan ikan yang mereka dapatkan dari ngerakat (menangkap ikan di laut)[1].

World Trade Organization (WTO) menjelaskan [2] dampak positif pariwisata bagi perkembangan ekonomi yaitu menghindari kosentrasi penduduk dan penyebaran aktifitas ekonomi, objek pariwisata dipilih di daerah pinggiran, pegunungan, pantai dan lokasi eksotis dan lainnya. Lokasi yang dekat dari pusat konsentrasi penduduk (kota) sehingga membantu penduduk dalam penyebaran aktifitas ekonomi ke wilayah lain. Gee dalam [3] mngemukakan bahwa selain dari dampak di bidang ekonomi, terdapat dampak positif pariwisata terhadap kondisi sosial budaya. Iamengemukakan bahwa dampak positif pariwisata antara lain: 1) Conservation of Cultural Heritage; adanya perlindungan untuk bendabenda kuno, bangunan sejarah, seni tradisional seperti musik, drama, tarian, pakaian, upacara adat. Adanya bantuan untuk perawatan musium, gedung teater, dan untuk dukungan acara-acara festival budaya, 2) Renewal of Cultural Pride; dengan adanya pembaharuan kebanggaan budaya maka masyarakat dapat memperbaharui kembali rasa bangga mereka terhadap peninggalan-peninggalan bersejarah ataupun budaya, 3) Cross Cultural Exchange; pariwisata dapat menciptakan per-tukaran budaya dari wisatawan dengan masyarakat setempat, sehingga membuat para wisatawan mengerti tentang budaya setempat dan mengerti nilai-nilai dari tradisi masyarakat setempat begitu pula sebaliknya masyarakat lokal bisa tahu tentang budaya dari para wisatawan tersebut baik yang domestik maupun internasional.

Demikian juga Cohen [4] mengelompokkan dampak sosial budaya ke dalam sepuluh kelompok besar yaitu: 1) dampak terhadap keterkaitan dan keterlibatan antara masyarakat setempat dengan masyarakat yang lebih luas, termasuk tingkat otonomi atau ketergantungannya; 2) dampak terhadap hubungan interpersonal antara anggota masyarakat; 3) dampak terhadap dasar-dasar organisasi/kelembagaan sosial; 4) dampak terhadap migrasi dari dan ke daerah pariwisata; 5) dampak terhadap ritme kehidupan sosial masyarakat; 6) dampak terhadap pola pembagian kerja; 7) dampak terhadap stratifikasi dan mobilitas sosial; 8) dampak terhadap distribusi pengaruh kekuasaan; 9) dampak terhadap meningkatnya penyimpangan-penyimpangan sosial, dan 10) dampak terhadap bidang kesenian dan adat istiadat

Namun demikian, segi positif kepariwisataan cukup banyak, hal itu dapat kita lihat di lapangan seperti halhal sebagai berikut:

1. Strutukur sosial seperti terjadi transisi kesempatan kerja dari sektor perpetanian ke sektor pelayanan, modernisasi dalam cara-cara perpetanian dan penjualan hasil panen, berkurangnya perbedaan dalam pendidikan dan kesempatan berusaha/pekerjaan, dan adanya pemerataan pendapatan masyarakat di daerah tujuan wisata yang dikunjungi wisatawan.

2. Modernisasi keluarga seperti kaum perempuan memperoleh status baru dari pepetani tradisional berubah menjadi pedagang, pemilik toko cindera mata, restoran atau bekerja sebagai karyawan hotel/kerajinan tangan dan terjadi kelonggaran perlakuan orang tua terhadap anak-anak.

3. Peningkatan dalam wawasan masyarakat seperti terjadinya perubahan tingkah laku ke arah yang positif terutama dalam etiket dan cara berkomunikasi antar sesama dan dapat menghilangkan prasangkaprasangka negatif terhadap etnis lain [5].

Melihat dampak positif yang ditimbulkan dengan adanya kepariwisataan di Desa Batu Layar sudah jelas kiranya terjadi pergeseran sebelum dan sesudah adanya kepariwisataan, di mana masya-rakat yang dahulunya hanya mengandalkan hasil nelayan kini sudah mulai berkembang menjadi bagian dari kepariwisataan itu sendiri, seperti sebagai penyedia sarana pariwisata, pemandu pariwisata, dan bekerja disektor kepariwisataan.

Dinamika perkembangan kepariwisataan selain memberikan dampak positif juga menimbulkan dampak negatif, terutama menyangkut masalah ketidak cocokan produk lokal dengan permintaan pasar pariwisata, hal ini terjadi jika suatu produk yang secara tradisional dihasilkan di daerah tujuan wisata tidak dapat diserap oleh pariwisata karena kurang diminati wisatawan[4]. Lebih lanjut Gee dalam [3] mengemukakan bahwa dampak negatif kepariwisataan terhadap sosial budaya antara lain; 1) Overcrowding and loss of amenities for residents; setiap pengelola objek wisata selalu menginginkan tempat wisata untuk menarik wisatawan baik domestik maupun internasional, tetapi ada hal-hal yang harus diperhitungkan karena apabila suatu objek wisata terlalu padat, menyebabkan hilangnya kenyamanan bagi penduduk dan membuat masyarakat 
setempat menjadi tidak nyaman dan pada akhirnya terbentuk garis batas antara penduduk lokal setempat dengan wisatawan yang terlalu banyak, 2) Cultural impacts; karena ingin menyuguhkan sesuatu yang diinginkan wisatawan tanpa disadari mereka sudah terlalu mengkomersi-alkan budaya sehingga tanpa sadar telah mengurangi dan mengubah sesuatu yang khas dari adat mereka atau bahkan mengurangi nilai suatu budaya yang seharusnya bernilai religius. Contoh; upacara agama yang seharusnya dilakukan dengan khidmat dan khusyuk, tetapi untuk menyuguhkan apa yang diinginkan oleh wisatawan maka mereka mengkomersialkan upacara tersebut untuk wisata-wan sehingga upacara agama yang dulunya khidmat dan khusyuk makin lama makin berkurang. Selanjutnya adanya kesalahpahaman dalam hal berkomunikasi, budaya, dan nilai agama yang dapat mengakibatkan sebuah konflik, 3) Sosial Problems; adanya percampuran budaya negatif antara wisatawan dengan masyarakat setempat[6].

Memberikan batasan yang lebih jelas mengenai dampak negatif sosial budaya pengembangan pariwisata dilihat dari respon masyarakat lokal terhadap keberadaan pariwisata seperti adanya perselisihan atau konflik kepentingan di antara para stakeholders, kebencian dan penolakan terhadap pengembangan pariwisata, dan munculnya masalah-masalah sosial[7].

Dari semua dampak yang diakibatkan dengan adanya kepariwisataan di Desa Batu Layar dapat mempengaruhi semua bidang dalam kehidupan masyarakat setempat seperti tingkat otonomi atau ketergantungan, hubungan interpersonal antara anggota masyarakat, stratifikasi dan mobilitas sosial, pola pembagian kerja yang meyerap masyarakat di bidangbidang kepariwisataan.

Paparan di atas menandakan perkembangan kepariwisataan dapat memberikan dampak yang positif terhadap kebudayaan. Di sini terjadi akulturasi kebudayaan, karena adanya interaksi masyarakat lokal dengan wisatawan, kebudayaan-kebudayaan daerah terus berkembang dengan adanya wisatawan (orang asing) yang datang berkunjung untuk melihat dan mengenal lebih dekat kebudayaan asli tersebut. Hal ini tentunya juga menyebabkan terjadinya penggalian nilainilai budaya asli untuk dikembangkan dan dilestarikan. Dengan demikian pola kebudayaan tradisional seperti tempat-tempat bersejarah, kesenian, dan adat istiadat akan tetap terpelihara dan lestari (sustainable). Desa Batu Layar sebagai kawasan wisata dapat melestrikan nilai budaya seperti makam Batu Layar dan Pura Batu Bolong yang setiap tahunnya di kunjungi masyarakat setempat dan wisatawan domestik atau wisatawan asing.

Mencermati dampak positif dan negatif dari kepariwisataan tentunya akan berpengaruh terhadap kondisi ekonomi, sosial, budaya masyarakat di daerah tujuan wisata. Demikian halnya dengan Desa Batu Layar yang merupakan salah satu daerah tujuan wisata, tentunya berpengaruh terhadap kondisi sosial budaya masyarakat Desa Batu Layar. Oleh karena itu penelitian ini ingin mengetahui bagaimana pergeseran nilai sosial budaya masyarakat Batu Layar sebagai dampak dari pariwisata.

\section{B. METODE PENELITIAN \\ 1. Pendekatan Penelitian}

Penelitian ini menggunakan pendekatan kualitatif dengan metode deskriptif. Pemilihan pendekatan dianggap tepat karena peneliti menggambarkan keadaan pariwisata dan pergeseran nilai sosial budaya di Desa Batu Layar Kecamatan Batu Layar Kabupaten Lombok Barat. Hal ini sejalan dengan maksud penelitian kualitatif menurut Bodgan dan Taylor dalam [8] yang mengatakan bahwa penelitian kualitatif adalah sebagai prosedur penelitian yang menghasilkan data deskriptif berupa kata-kata tertulis atau lisan dari orang-orang dan perilaku yang dapat diamati.

\section{Subyek Penelitian}

Subyek penelitian adalah orang yang memberikan informasi tentang situasi dan kondisi tempat penelitian[8]. Pengambilan informan dilakukan secara purvosive sampling yakni yang menjadi informan sudah ditentukan sebelumnya berdasarkan tujuan penelitian[9]. Selain menggunakan purposive sampling, peneliti juga menggunakan teknik Snowball Sampling yakni teknik pengambilan sampel dimana sumber data yang pada awalnya jumlahnya sedikit, lama-lama menjadi besar. Dalam teknik snowball sampling, Informan penelitian yang pertama setelah diwawancara kemudian memberikan rekomendasi kepada peneliti terhadap informan berikutnya yang mengetahui persis tentang pergeseran nilai sosial budaya. Begitu juga dengan informan kedua, informan kedua juga memberikan rekomendasi kepada peneliti terhadap siapa yang diwawancara oleh peneliti. Begitu selanjutnya sampai pada keterangan-keterangan yang diporeleh sama, maka data yang terkumpul sudah dirasakan cukup dan tidak perlu menambah informan lagi karena informasi yang didapat dari para informan sudah sama.

Informan yang diwawancara memiliki mata pencaharian yang berbeda-beda yakni ada yang bekerja sebagai Tokoh Agama, kepala Dusun, Tutor PAUD dan termasuk Staf Desa serta Sekertaris Desa Batu Layar yang bergerak di bidang pariwisata. Tingkat pendidikan juga berbeda di mana tamatan SMA satu orang, SLTA dua orang dan tamatan D2 satu orang D3 satu orang.

\section{Teknik Pengumpulan Data}

Adapun teknik yang digunakan dalam mengumpulkan data lapangan adalah:

a. Observasi 
Observasi adalah dasar semua ilmu pengetahuan, para ilmuan hanya dapat bekerja berdasarkan data, yaitu fakta mengenai dunia kenyataan yang diperoleh melalui observasi menurut Nasution dalam [10]. Teknik ini dilakukan untuk membuktikan kebenaran data atau informasi yang diperoleh melalui teknik wawancara. Pengumpulan data dengan teknik ini dimaksudkan untuk mengantisipasi kekurangan-kekurangan yang ada atau tidak dapat diungkapkan dalam wawancara. Observasi yang peneliti lakukan ialah observasi lansung dan tidak lansung. Observasi lansung yaitu dengan melakukan kunjungan kekawasan wisata Desa Batu Layar. Aspek-aspek yang peneliti observasi seperti sikap dan perilaku masyarakat sekitar, serta keberadaan sarana dan prasarana penunjang kepariwisataan.

\section{b. Interview (wawancara)}

Wawancara adalah percakapan dengan maksud tertentu oleh dua pihak, yaitu pewawancara (interviewer) sebagai pemberi pertanyaan dan yang diwawancarai (interviewer) sebagai pemberi jawaban atas pertanyaan itu[8]. Peneliti menggunakan metode wawancara untuk mendapatkan gambaran tentang pariwisata dan pergeseran nilai sosial budaya yang terjadi di Desa Batu Layar. Wawancara dilakukan terhadap informan penelitian yakni tokoh masyarakat termasuk di dalamnya tokoh agama dan tokoh adat Desa Batu Layar.

Wawancara peneliti lakukan dengan teknik terstruktur. Wawancara terstruktur adalah wawancara yang dilakukan dengan mengajukan beberapa pertanyaan yang diajukan dan telah disusun sebelumnya.Wawancara tidak terstuktur adalah wawancara dengan mengajukan beberapa pertanyaan secara lebih leluasa tanpa terkait oleh susunan pertanyaan yang telah dipersiapkan sebelumnya, biasanya pertanyaan muncul secara spontan sesuai dengan perkembangan situasi dan kondisi ketika melakukan wawancara, dalam wawancara peneliti memanfaatkan tipe recorder untuk merekam hasil wawancara dengan informan. Pertimbangan peneliti menggunakan tipe recorder ini adalah semata-mata agar proses pengambilan data lebih efektif dan efisien pada saat berada di lapangan. Peneliti melakukan wawancara terhadap tokoh masyarakat, tokoh agama dan tokoh adat dengan mengajukan beberapa pertanyaan kemudian direkam. Di akhir wawancara, hasil rekaman ini kemudian peneliti tulis kembali dalam buku catatan hasil penelitian.

\section{c. Dokumentasi}

Tehnik dokumentasi adalah suatu cara pengumpulan data yang menghasilkan catatan-catatan penting yang berhubungan dengan masalah yang diteliti, sehingga diperoleh data yang lengkap, bukan berdasarkan perkiraan. Metode ini hanya mengambil data yang sudah ada seperti indeks prestasi, jumlah anak, pendapatan, luas tanah, jumlah penduduk, dan sebagainya[8].
Dokumen-dokumen yang peneliti kumpulkan antara lain; keterangan pertanggung jawaban kepala Desa Batu Layar masa bakti 1999/ 2000, monografi Desa Batu Layar, data penduduk Desa Batu Layar, sensus ekonomi Desa batu Layar dari Badan Pusat Statistik Provinsi Nusa Tenggara Barat.

\section{Tehnik Analisis Data}

Metode pengumpulan data yang digunakan dalam penelitian ini adalah metode analisis data kualitatif. Analisis kualitatif untuk menghasilkan data deskriptif tentang pergeseran nilai sosial budaya yang terjadi di Desa Batu Layar. Adapun tahap-tahap yang dilakukan dalam analisis data ini menurut [11] sebagai berikut.

Pertama, reduksi data merupakan suatu bentuk analisis yang menajamkan, menggolongkan, mengarahkan, membuang yang tidak perlu dan mengorganisasikan data dengan cara sedemikian rupa sehingga kesimpulankesimpulan finalnya dapat ditarik. Kedua, penyajian data adalah sekumpulan informasi tersusun yang memberikan kemungkinan adanya penarikan kesimpulan dan pengambilan tindakan. Ketiga, Menarik kesimpulan, data diolah dalam rangka membuat kesimpulan hasil penelitian yang dituangkan dalam bentuk pembahasan.

\section{HASIL DAN PEMBAHASAN}

\section{Dampak Kepariwisataan Di Desa Batu Layar}

Dampak kepariwisataan di desa Batulayar terdapat berbagai sarana pariwisata yang ada di kawasan tersebut seperti biro perjalanan wisata, transportasi angkutan wisata, akomodasi (hotel, vila, cafe, bar serta restoran) semua sudah ada. Vila yang ada di Batu Layar di dalamnya juga terdapat cafe, bar, dan restoran yang jumlah sekitar 21 unit seperti Alberto (Restoran, Bar, Pizzeria), Egi Cafe, Green Cafe, Rirye Cafe, restaurant Batu Bolong, Cafe Wayan Bakery, warung Compoeng Pasar Seni, Cristal Cafe, Q-lank Cafe, dan lain-lain. Hotel yang ada di sekitar wilayah Batu Layar jumlahnya sebanyak 5 unit seperti Hotel Bintang Senggigi, Hotel Atithi Sanggraha, Hotel Pondok Asri, Hotel Jayakarta, Hotel Karolina. Prasarana pariwisata seperti perhubungan, listrik, air bersih, perbankan, alat telekomunikasi, keamanan dan pasar tradisional sudah ada kecuali rumah sakit tidak ada, tapi yang ada hanya puskesmas.

Selain itu, sarana lain yang ada di daerah wisata Batu Layar ini adalah tempat karaoke yang biasanya menyatu dengan café. Adapun tempat-tempat karaoke yang dapat ditemui di Batu Layar ialah seperti New OMA SITTARD, Bellina, Lian Galery, dan Mekar Café.

Kehidupan sosial budaya mayarakat Desa Batu Layar sangat dipengaruhi oleh situasi dan kondisi fisik lingkungan setempat, yaitu dengan adanya kepariwisataan terdapat sarana pariwisata yang menyebabkan timbulnya beragam mata pencaharian sehingga meningkatkan pendapatan masyarakat yang terserap bekerja di kawasan wisata. 
Kehidupan masyarakat Desa Batu Layar dalam mengikuti tradisi kebudayaan islam seperti adanya kegiatan-kegiatan keagamaan misalnya Maulid Nabi Muhammad SAW, Isra'Mi'raj, perkawinan, dan dalam perayaan hari-hari besar agama, di mana dalam kenyataannya menunjukan bahwa di Desa Batu Layar masih memegang teguh nilai-nilai adat istiadat atau kebudayaan masyarakat setempat yang tinggal di daerah kawasan wisata.

Penduduk masyarakat Batu Layar sebagian kecil sekitar 25\% bekerja di sektor pariwisata sedangkan sebagian besar sebagai petani. Daya tarik pariwisata di desa batu layar ini adalah keindahan alamnya. Adanya pariwisata di Batu Layar ini ada dampak positifnya, antara lain: penyerapan tenaga kerja, peningkatan hasil ekonomi masyarakat yang lemah mempunyai peningkatan dalam penghasilan, kawasan pariwisata ini banyak menyerap tenaga kerja mulai dari buruh kasar sampai teknisi. Dampak negatif pariwisata dalam bidangekonomi seperti harga tanah, makanan dan minuman di kawasan batu layar lebih mahal di bandingkan dengan sebelum adanya kawasan pariwisata.

Industri kerajinan sebelum pariwisata tidak ada dan setelah adanya kawasan pariwisata industry kerajinan seperti ukir-ukiran patung, gerabah, gelang yang dibuat dari karang di kawasan pariwisata ada perkembangan dan berpengaruh pada pendapatan masyarakat, tingkat kesenjangan ekonomi bisa dikategorikan menengah ke bawah. Peran perempuan dalam bidang industri pariwisata adalah sebagai pekerja hotel, restoran, café. Sebelum adanya kepari-wisataan, masyarakat Batu Layar pada waktu pukul 21.0o WITA sudah mulai sepi, akan tetapi dengan adanya kepariwisataan ini, pada pukul 21.00 WITA sampai pukul 01.0o WITA terlihat masih banyak masyarakat yang beraktifitas seperti halnya dengan kehidupan di kota-kota besar.

Masyarakat Batu Layar sebelum pariwisata berperilaku dan berpakaian memakai batik, sarung dan setelah pariwisata telah terjadi perubahan gaya hidup dengan adanya kunjungan wisatawan lokal dan wisatawan manca-negara. Masyarakat Desa Batu Layar sangat menerima kedatangan wisatawan yang datang berkunjung ke daerahnya yang merupakan kawasan pariwisata. Mata pencaharian masyarakat Desa Batu Layar sebelum pariwisata sebagian besar petani dan nelayan dan sekarang memiliki beragam mata pencaharian dengan adanya kawasan wisata yaitu karyawan hotel, café, restoran, villa, bar dan tukang kebun.

Menurut hasil penelitian ditemukan beberapa dampak pariwisata di desa batulayar, berikut uraianya:

"Dalam hal minum-minuman beralkohol di Batu Layar sebelum pariwisata tidak ada yang mabukmabukan dan setelah ada pariwisata dengan ramainya tempat-tempat hiburan sebagian masyarakat Desa Batu Layar yang minum- minuman beralkohol tersebut.Kondisi jalan raya sebelum pariwisata yaitu kecil dan tidak ramai dan setelah pariwisata jalan ramai dan tidak macet berlalu lintas karena jalan luas kecuali pada hari lebaran ketupat. Tindak kejahatan yang terjadi adalah pencurian dan setelah pariwisata terjadi perampokan.Cagar budaya di masyarakat Batu Layar masih dilestarikan seperti halnya ziarah makam yang biasanya disertai dengan lebaran ketupat". (Wawancara 13/09/2018) informa 1.

Penduduk masyarakat Desa Batu Layar sebagian kecil bekerja di bidang pariwisata. Hal yang menjadi daya tarik pariwisata di Desa Batu Layar adalah Keindahan pantai dan keindahan dalam laut. harga makanan dan minuman sebelum adanya pariwisata sangat rendah dan sekarang harga makanan dan minuman setelah pariwisata melajur tinggi hampir mencapai sepuluh kali lipat. Harga tanah di Desa Batu Layar sebelum pariwisata sangat rendah dengan harga Rp. 100.000 per satu are. Setelah adanya kawasan pariwisata harga tanah menjadi sangat tinggi mencapai Rp. 25.000.000 sampai dengan 100.000.000 per are. Masyarakat Batu Layar yang bekerja di kawasan pariwisata memiliki peningkatan pendapatan hanya mencapai o\% sampai dengan 5\% dari 100\% yang diharapkan pemerintah dikarenakan pengusaha dan infestor tidak menggunakan masyarakat setempat sebagai tenaga kerja di bidang pariwisata melainkan 95\% tenaga kerja adalah orang luar daerah.Kerajinan industri di Desa Batu Layar berkembang secara lamban dan dulu sebelum pariwisata tidak ada industri kerajinan.

Dengan adanya kawasan wisata di Desa Batu Layar ada peningkatan pendapatan mencapai $5 \%$. Tingkat kesenjangan ekonomi masyarakat Desa Batu Layar dikatakan menegah ke bawah. Bentuk keterlibatan perempuan dalam kawasan pariwisata adalah pembantu rumah tangga, karyawan hotel, dan café.

Dampak lainnya pada perubahan ekonomi dan budaya masyarakat desa Batulayar dalam menghadapi perkembangan pariwisata yang berkembang cepat, menurut informan menjelaskan bahwa:

"Masyarakat Desa Batu Layar sebelum adanya kawasan pariwisata tidak ada yang meminumminuman beralkohol dan sekarang dengan adanya pariwisata sering meminum-minuman beralkohol. Kondisi jalan raya sebelum pariwisata sangat kecil dan tidak bagus serta sepi dan setelah adanya pariwisata jalan raya luas dan bagus serta tidak ada kemacetan lalu lintas kecuali pada hari-hari tertentu seperti hari lebaran ketupat. Kejahatan yang terjadi sebelum pariwisata yaitu pencurian dan sekarang setelah pariwisata selain pencurian terjadi perampokan, pemerkosaan. Cagar budaya yang ada di Desa Batu Layar adalah sejarah Batu Layar, Batu yang berbentuk perahu dan konon dapat berjalan di atas air, 
ziarah makam keramat yang disertai dengan lebaran ketupat sampai saat ini" (Wawancara 28/09/2019).

Penduduk masyarakat Desa Batu Layar sebagian kecil bekerja di kawasan wisata.Hal yang menjadi daya tarik pariwisata di Desa Batu Layar yaitu Keindahan pantainya yang dapat dinikmati atau dilihat dari bukitbukit yang ada disekitarnya. Harga makanan dan minuman sebelum adanya pariwisata cukup murah dan sekarang harga makanan dan minuman setelah pariwisata mulai naik dan relatif mahal. Harga tanah di Desa Batu Layar sebelum pariwisata cukup murah dan masih bisa terjangkau oleh masyarakat sekitar dan Setelah adanya kawasan pariwisata harga tanah menjadi sangat meningkat sehingga masyarakat tidak mampu untuk membeli. Masyarakat Desa Batu Layar yang bekerja di kawasan pariwisata dengan lapangan kerja semakin terbuka sehingga peningkatan pendapatan masyarakat dapat meningkat.

Dengan adanya kawasan pariwisata di Desa Batu Layar membutuhkan banyak tenaga kerja. Kerajinan industri di Desa Batu Layar berkembang secara lamban dan dulu sebelum pariwisata tidak ada industri kerajinan.Dengan adanya kawasan wisata di Desa Batu Layar sangat mempengaruhi tingkat pendapatan masyarakat.

Tingkat kesenjangan ekonomi masyarakat di Desa Batu Layar yaitu menegah ke bawah. Bentuk keterlibatan perempuan dalam kawasan pari-wisata adalah sebagai karyawan hotel, café.

Masyarakat Desa Batu Layar sebelum adanya kawasan pariwisata tidak ada yang meminum-minuman beralkohol dan sekarang dengan adanya pari-wisata sebagian biasa meminum-minuman beralkohol.

"Masyarakat Desa Batu Layar dalam bertingkah laku sering mengikuti wisatawan misalnya dari segi berpakaian.Kondisi jalan raya sebelum pariwisata sangat buruk dan tidak bagus serta sepi dari transportasi dan setelah adanya pariwisata kondisi jalan raya angkutan transportasi yang ramai kedatangan wisatawan yang berkujung serta tidak ada kemacetan lalu lintas kecuali pada hari-hari tertentu seperti hari lebaran ketupat dan hari libur sekolah. Kejahatan yang terjadi sebelum pariwisata adalah pencurian dan sekarang setelah pariwisata yaitu pencurian terjadi juga perampokan.Cagar budaya yang ada di Desa Batu Layar adalah anjung-anjung ziarah makam keramat”. (Wawancara 09/02/2019).

Telah terjadi pergeseran nilai sosial budaya di Desa Batu Layar. Dari segi sosial telah nampak pergeseran seperti Masyarakat yang bekerja di kawasan pariwisata dengan lapangan kerja semakin terbuka sehingga peningkatan pendapatan masyarakat dapat meningkat. Dari segi budaya telah terjadi pergeseran dalam perilaku dan gaya hidup masyarakat mulai berubah.

Dengan adanya kawasan wisata di Desa Batu Layar sangat mempengaruhi tingkat pendapatan masyarakat. Tingkat kesenjangan ekonomi mas-yarakat di Desa Batu
Layar yaitu menengah ke bawah.Bentuk keterlibatan perempuan dalam kawasan pariwisata adalah sebagai karyawan hotel.

"Cara berpakaian masyarakat Desa Batu Layar memakai sarung atau batik dan sekarang memakai celana. Masyarakat Desa Batu Layar sebelum adanya kawasan pariwisata tidak ada yang meminum-minuman beralkohol dan sekarang dengan adanya pariwisata sebagian biasa meminum-minuman beralkohol. Masyarakat Desa Batu Layar dalam bertingkah laku sering mengikuti wisatawan.Kondisi jalan raya sebelum pariwisata tidak bagus serta sepi dari transportasi dan setelah adanya pariwisata kondisi jalan raya ramai serta tidak ada kemacetan lalu lintas kecuali pada hari-hari tertentu seperti hari lebaran ketupat. Kejahatan yang terjadi sebelum pariwisata adalah pencurian dan sekarang setelah pariwisata selain pencurian dan perampokan. Cagar budaya yang ada di Desa Batu Layar adalah ziarah makam keramat”. (Wawancara 04/10/2018).

Terjadi pergeseran nilai sosial budaya di Desa Batu Layar. Dari segi sosial telah nampak pergeseran seperti Masyarakat yang bekerja di kawasan pariwisata ada peningkatan pendapatan. Dari segi budaya telah terjadi pergeseran sebelum adanya kawasan pariwisata tidak ada yang meminum-minuman beralkohol dan sekarang dengan adanya pariwisata sebagian masyarakat biasa meminum-minuman beral-kohol.

Sebagian kecil masyarakat batu layar bekerja di sektor pariwisata. Prasarana seperti air, listrik, perbankan, puskesmas, pasar seni, prasarana pariwisata sudah memadai, sarana pariwisata yang ada yakni hotel, café, vila, restoran. Adapun hal yang menjadi daya tarik pariwisata adalah panorama alamnya.

Dampak positif pariwisata dalam bidang ekonomi adalah memberikan masyarakat kesempatan bekerja di hotel, café, pembersihan jalan untuk meningkatkan penghasilan sedangkan dampak negatif yang ditimbulkan seperti: meningkatnya harga sembako. Masyarakat Desa Batu Layar yang bekerja di kawasan pariwisata ada peningkatan pendapatan. Keberadaan kawasan pariwisata di Desa Batu Layar membutuhkan banyak tenaga kerja. Kerajinan industri di Desa Batu Layar berkembang secara pelan, sebelum pariwisata tidak ada industri kerajinan.

Dengan adanya kawasan wisata di Desa Batu Layar sangat mempengaruhi tingkat pendapatan masyarakat. Tingkat kesenjangan ekonomi masyarakat di Desa Batu Layar yaitu menegah ke bawah. Bentuk keterlibatan perempuan dalam kawasan pariwisata adalah bekerja di hotel dan café, Mata pencaharian masyarakat Desa Batu Layar sebagai pepetani dan nelayan dan dengan adanya kawasan wisata mempunyai mata pencaharian yang beragam seperti buruh bangunan, tukang kebun, karyawan hotel, café dan bar.

Cara berpakaian masyarakat Desa Batu Layar memakai sarung dan sekarang memakai pakaian mini, jeans, celana pendek. Cara berperilaku masyarakat 
setempat sebelum pariwisata yaitu berperilaku baik, sopan santun sedangkan sesudah adanya pariwisata perilaku kurang baik.Masyarakat Desa Batu Layar sebelum adanya kawasan pariwisata tidak ada yang meminum-minuman beralkohol dan sekarang dengan adanya pariwisata sebagian masyarakat meminumminuman beralkohol terutama remaja.

"Masyarakat Desa Batu Layar dalam bertingkah laku sering mengikuti wisatawan. Kondisi jalan raya sebelum pariwisata sempit serta sepi dan setelah adanya pariwisata kondisi jalan raya ramai serta tidak ada kemacetan lalu lintas kecuali pada hari-hari tertentu seperti hari lebaran ketupat.Kejahatan yang terjadi sebelum pariwisata adalah pencurian dan sekarang setelah pariwisata terjadi pencurian dan perampokan.Cagar budaya yang ada di Desa Batu Layar adalah ziarah makam keramat." (Wawancara 01/10/2018).

Segi sosial telah nampak pergeseran yaitu masyarakat mempunyai mata pencaharian yang beragam seperti buruh bangunan, tukang kebun, karyawan hotel, café dan bar. Dari segi budaya telah terjadi pergeseran dalam tata cara berpenampilan sepertimemakai sarung dan sekarang memakai pakaian mini, jeans, celana pendek sering mengikuti wisatawan.

\section{Pergeseran Nilai Social Budaya Akibat} Adanya Pariwisata

Mata pencaharian penduduk Desa Batu Layar sangatlah baragam. Keberagaman itu bisa dilihat dari beraneka ragam mata pencaharian, mulai dari pepetani, nelayan, pedagang, swasta, PNS dan lain-lain. Jumlah penduduk Desa Batu Layar dari tahun ketahun mengalami pertumbuhan yang cukup signifikan. Ini bisa dilihat dari pertamba-han penduduknya yang setiap tahun mengalami peningkatan. Dari data tiga tahun terakhir yaitu tahun 2005 jumlah penduduknya 9.675 jiwa bertambah menjadi 9.844 pada tahun 2006. pada tahun 2008 penduduk Desa Batu Layar berjumlah 12799 jiwa.

Keberadaan kepariwisataan di Desa Batu Layar menyebabkan kemacetan lalu lintas di daerah kawasan wisata dengan kunjungan wisatawan asing maupun wisatawan domestik yang berkunjung pada hari-hari tertentu seperti acara keagamaan dan hari libur sekolah sering terjadi kemacetan lalu lintas di Desa Batu Layar sebagai kawasan wisata.

Dengan demikian pergeseran nilai budaya (perubahan kultural) terhadap adanya pariwisata dapat diuraikan beberapa factor yang mempengaruhi, yaitu:

a. Transformasi tata nilai

Transformasi tata nilai dapat di lihat dari efek peniruan masyarakat Desa Batu Layar dari segi perubahan penampilan yang paling cepat ditiru masyarakat setempat terutama muda-mudi. Perubahan penampilan masyarakat seperti tata cara berpakaian mini yang disebabkan dengan adanya kepariwisataan. Masyarakat Desa Batu Layar yang tinggal di kawasan wisata, perilaku dan gaya hidup masyarakat mulai berubah seperti mengkonsumsi meminum-minuman beralkohol.

Dampak tata nilai yang perpengaruh adalah pada cara berpakaian yang mengikuti kebaratan,

"Berpakaian memakai kebaya, sarung, batik memakai pakaian mini sopan santun dan adat istiadat di junjung tinggi adat-istiadat sudah mulai punah. Sebagaian masyarakat mengikuti tingkah laku wisatawan misalnya konsumsi minuman alcohol, berjoget, berdansa dan sebagainya" (Wawancara 01/10/2018).

Akibat adanya perilaku wisatawan asing yang masuk, maka masyarakat local tidak mampu mempertankan budaya lokalnya sehingga karena adanya tekan pekerjaan, keterbatasan kemampuan mereka akhirnya mengikuti kemauan para wisatawan yang masuk ke batu layar.

b. Kehidupan malam yang ramai

Banyaknya tempat-tempat hiburan membuat sebagian masyarakat setempat mudah terpengaruh bagi masyarakat local, dimana tempat hiburan ini seperti café mulai dibuka pada pukul 21.00 wita sampai pukul 01.00 wita terlihat ramai dengan orang-orang dan suara musik yang keras, dan para pemuda pemudi ikut mengkonsumsi minuman beralkohol.

Sehingga berdampak pada kemacetan lalu lintas ini sering terjadi pada saat acara keagamaan dan hari libur sekolah karena banyak wisatawan yang datang berkunjung ke kawasan wisata Desa Batu Layar memakai Bus, Mobil, sepeda motor. Selain menyebabkan kemacetan lalu lintas, banyaknya kendaraan yang melintasi kawasan wisata Desa Batu Layar ini juga menyebabkan polusi udara dan polusi suara yakni kebisingan yang ditimbulkan oleh suara kendaraan-kendaraan yang melintas. Kunjungan wisatawan kedaerah wisata Batu Layar membuat pantai dan lahan parkir menjadi penuh dan membuat masyarakat setempat menjadi bising dengan arakan motor di sepanjang jalan kawasan wisata.

c. Gaya hidup masyarakat tinggi

Gaya hidup masyarakat sangat tinggi, dimana hargaharga bahan pokok sangat mahal, hal dipengaruhi oleh dampak adanya pariwisata mancanegara yang berkunjung di batu layar sehingga berdampak pada nilai ekonomi masyarakat cukup signifikan juga. Hal tersebut sesuai dengan pernyataan informan menjalaskannbahwa

"Sebagian kecil sekitar 25\% yang bekerja di bidang pariwisata karena sebagian besarnya bertani dan di Desa batu layar selain kekayaan budayanya batu layar di jadikan objek wisata dengan keindahan alamnya yang membuat wisatawan datang dari manca negara untuk berkunjung. Sebelum adanya pariwisa haraga sembako lebih murah dan setelah adanya 
pariwisata lebih mahal contohnya; kelapa muda yang harganya Rp.5oo menjadi Rp.25oo lebih mahal ada peningkatan pendapatan masyarakat" Wawancara 01/10/2018).

Selain itu, kebutuhan tenaga kerja sangat banyak juga terutama pada tenaga seni ukiran patung, gerabah, gelang yang dibuat dari Kerang. Bentuk keterlibatan tenaga perempuan yang bekerja di sektor pariwisata misalnya karyawan hotel, café, restoran, villa dan bar.

Dampak penjulaan tanah dikawasan pariwisata sangat tinggi terutama harga tanah sangat fantastis dan itu membawa dapat positif bagi masyarakat batulayar yang memiliki tanah untuk diperjual belikan uantuk kebutuhan pembagunan perhotelan dan lainnya. Hasil penjelasan informan menjelaskan bahwa

Harga penjualan tanah mencapai sepuluh kali lipat Sangat rendah dengan harga Rp.10o.ooo per satu are dan tinggi mencapai Rp.25.00o.ooo sampai dengan 100.00o.0oo per are $5 \%$ dari $100 \%$ yang diharapkan pemerintah dikarenakan pengusaha dan infestor tidak menggunakan masyarakat setempat, melainkan 95\% orang luar daerah dan sebagai tenaga kerja di bidang pariwisata membutuhkan banyak tenaga kerja. (wawancara, 17-09-2018).

Jadi perubahan social yaitu sebelum adanya kepariwisataan, masyarakat Batu Layar pada waktu pukul 21.0o WITA sudah mulai sepi, akan tetapi dengan adanya kepariwisataan ini, pada pukul 21.00 WITA sampai pukul 01.00 WITA terlihat masih banyak masyarakat yang beraktifitas. Sedangkan perubahan budaya yaitu masyarakat Batu Layar sebelum pariwisata berperilaku dan berpakaian memakai batik, sarung dan setelah pariwisata telah terjadi perubahan gaya hidup dengan adanya kunjungan wisatawan lokal dan wisatawan mancanegara.

\section{TEMUAN DAN DISKUSI}

Adanya factor pariwisata membawa dampak bagi kehdupan masyarakat desa batulayar pada umunya. Adapun dampak positif adalah meningkatkan nilai ekonomi masyarakat misalnya memberikan masyarakat kesempatan bekerja di hotel, café, pembersihan jalan untuk meningkatkan penghasilan. Sementara dampak negative yaitu Pertama, menimbulkan dampak yang berakibat pada kehidupan masyarakat yaitu harga kebutuhan bahan pokok menjadi lebih mahal jika dibandingkan dengan harga kebutuhan pokok di daerah lain yang bukan merupakan kawasan pariwisata. Kedua, ketidak nyamanan masyarakat karena semakin padatnya objek wisata. Ketidak nyamanan itu disebabkan karena masyarakat merasa terganggu oleh pariwisata yang membuat terganggunya aktifitas masyarakat yang bekerja di luar pariwisata. Khusus untuk hari besar Agama.

Pergeseran nilai sosial (perubahan struktural) yang terjadi dalam masyarakat adalah nilai yang dianut oleh suatu masyarakat, mengenai apa yang dianggap baik dan apa yang dianggap buruk oleh masyarakat. Sebagai contoh, orang menanggap menolong memiliki nilai baik, sedangkan mencuri bernilai buruk. Woods mendefinisikan nilai sosial sebagai petunjuk umum yang telah berlangsung lama, yang mengarahkan tingkah laku dan kepuasan dalam kehidupan sehari-hari. Untuk menentukan sesuatu itu dikatakan baik atau buruk, pantas atau tidak pantas harus melalui proses menimbang. Hal ini tentu sangat dipengaruhi oleh kebudayaan yang dianut masyarakat. tidak heran apabila antara masyarakat yang satu dan masyarakat yang lain terdapat perbedaan tata nilai[12]. Contoh, masyarakat Batu Layar yang tinggal di kawasan wisata mempunyai aktifitas sampai larut malam berbeda dengan sebelum masuknya kepariwisataan di Desa setempat aktifitasnya tidak sampai larut malam.

Aksi sosial merupakan bagian dari pekerjaan sosial yang memiliki komitmen untuk menjadi agen atau sumber bagi mereka yang berjuang menghadapi beragam masalah untuk memerlukan berbagai kebutuhan hidup. peluang kerja sektor pariwasata harus diakui memiliki beberapa kelebihan seperti, penyerapan tenaga kerja di kawasan pariwisata yaitu bekerja di café, hotel, restoran, bar dan lain sebagainya jika dibandingkan dengan sektor lainnya[13]. Hal ini menarik minat orang dari pekerjaan lain dan wilayah untuk masuk ke sektor pariwisata. Beberapa jenis pekerjaan yang tidak memerlukan keahlian khusus di sektor pariwisata, seperti tukang kebun, cleaning service, house keeping, dan sejenisnya menarik minat ibu rumah tangga atau pekerja di sektor berpetanian untuk bergabung.

Beberapa daerah yang umumnya sumber mata pencaharian sebagian besar berasal dari sektor berpetani segera mengalami tantangan. Terjadi transformasi pekerjaan dan tenaga kerja dari sektor perpetanian ke pariwisata. Hal tersebut juga ditemukan di daerah Batu Layar, dimana sebagian kecil masyarakat Desa Batu Layar sudah beralih profesi yang dulunya sebagian besar adalah pepetani. Dari data di atas juga menunjukkan dari segi mata pencaharian profesi wiraswasta pada tahun 2008 berjumlah 2075 lebih banyak dari pada pepetani dengan jumlah 1832. Ini menunjukkan telah terjadi pergeseran sistem mata pencaharian yang dilakukan oleh masyarakat Desa Batu Layar.

Kepariwisataan di Desa Batu Layar ini juga menimbulkan berkembangnya industri kerajinan sehingga menambah pilihan profesi bagi masyarkat sekitar. Selain itu, adanya kawasan wisata ini juga dapat menarik minat penduduk untuk berjualan baik dengan mendirikan warung ataupun dengan berjualan dengan cara mencari sendiri para pembeli atau yang biasa disebut dengan pedagang kaki lima.

Desa Batu Layar masyarakatnya memiliki beragam mata pencaharian atau penyerapan tenaga kerja di sektor pariwisata seperti halnya bekerja di hotel dan café yang memberikan potensi kepariwisataan dinilai sangat 
prospektif oleh kalangan pengusaha lokal dan internasional sehingga kondisi ini tentu membawa pengaruh positif terutama bagi penyediaan lapangan pekerjaan di bidang perhotelan dan café. Bahwa Pariwisata merupakan sektor yang tidak bisa berdiri sendiri tetapi memerlukan dukungan dari sektor lain baik sektor pariwisata maupun sektor-sektor lain yang berhubungan dengan sektor pariwisata tidak dapat dipungkiri merupakan lapangan kerja yang menyerap begitu banyak tenaga kerja sebagai gambaran seberapa besar penyerapan ekonomi dan penyerapan tenaga kerja yang terlibat dalam kegiatan pariwisata. [2]

Perubahan demografis disuatu daerah biasanya cenderung terus bertambah, mengakibatkan terjadinya perubahan diberbagai sektor kehidupan, bidang perekonomian, pertambahan penduduk mem-pengaruhi persedian kebutuhan pangan, sandang, dan papan[13].

Kedatangan wisatawan ke daerah wisata Batu Layar membuat sesaknya orang dengan jumlah yang begitu besar yang datang baik wisatawan lokal maupun wisatawan asing. Desa Batu Layar sebagai tujuan wisata dikunjungi wisatawan yang datang rekreasi dari berbagai daerah meramaikan pantai Batu Layar dengan kedatangan wisatawan. Kepadatan penduduk di Desa Batu Layar yang disebabkan oleh banyaknya wisatawan lokal, wisatawan asing dan masyarakat setempat yang datang berkunjung ke daerah wisata Batu Layar untuk bersama-sam merayakan dan menyaksikan acara tahunan Hari Lebaran Topat.

Kemacetan lalu lintas ini sering terjadi pada saat acara keagamaan dan hari libur sekolah karena banyak wisatawan yang datang berkunjung ke kawasan wisata Desa Batu Layar memakai Bus, Mobil, sepeda motor. Selain menyebabkan kemacetan lalu lintas, banyaknya kendaraan yang melintasi kawasan wisata Desa Batu Layar ini juga menyebabkan polusi udara dan polusi suara yakni kebisingan yang ditimbulkan oleh suara kendaraan-kendaraan yang melintas. Kunjungan wisatawan kedaerah wisata Batu Layar membuat pantai dan lahan parkir menjadi penuh dan membuat masyarakat setempat menjadi bising dengan arakan motor di sepanjang jalan kawasan wisata.

Transformasi tata nilai ini seperti, efek peniruan masyarakat. Nampak terjadi di masyarakat Desa Batu Layar ialah dari segi perilaku para muda-mudi. Perilaku itu seperti cara berpenampilan yang sudah modern mengikuti cara berpakaian para wisatawan mancanegara. Perilaku tersebut seperti mengecat rambut, memakai anting-antingan besar bagi yang laki-laki, minumminuman beralkohol. Sedangkan pada kaum hawa perilaku yang agak kebarat-baratan yang terlihat seperti cara berpakaian yang minim, melakukan cat rambut. Perilaku tersebut hanya dilakukan oleh sebagian kecil saja dari pemuda/ pemudi Desa Batu Layar, akan tetapi, dalam acara-acara adat para muda-mudi ini tetap menggunakan pakaian adat mereka. Selain itu, adanya perubahan masyarakat Desa Batu Layar, khusunya dari sisi perubahan penampilan yang paling cepat proses perubahanya, karena sifat wisatawan yang terlalu bebas dalam berperilaku dan berpenampilan di daerah wisata.

Pada aspek budaya seperti tradisi, keagamaan dan bahasa umunya tidak mengalami perubahan. Tradisi masyarakat Desa Batu Layar masih tetap walaupun budaya-budaya asing yang dibawa oleh wisatawan yang berkunjung ke daerahnya. Salah satu trdisi yang sampai saat ini masih dilestarikan oleh masyarakat Desa Batu Layar ialah lebaran topat. Pelaksanaan kegiatan lebaran topat ini juga melibatkan pemerintah dan juga wisatawan asing selain dari pada tokoh-tokoh masyarakat yang ada. Hal tersebut sejalan dengan penelitian yang menjelaskan bahwa pengaruh globalisasi terhdap nilai-nilai budya pada masyarakat sudah mulai terpengaruh dimana nilai-nilai atau kebiasaan yang sudah dilakukan oleh masyarakat setempat yang merekat dan memperkuat lantai menggunakan kotoran kerbau. Juga terlihat dari bentuk bangunan rumah masyarakat yang sudah banyak meniggalkan keaslian dari rumah teradisional tersebut. Hal ini membuat nilainilai budaya pada rumah tradisional masyarakat sedikit mengalami perubahan[14].

Selain tradisi lebaran topat, di Batu Layar ini juga terdapat sebuah makam yang dianggap keramat oleh masyarakat Batu layar khusunya dan masyarakat lombok umumnya, masih banyak dikunjungi oleh para peziarah baik masyarakat setempat maupun masyarakat yang berasal dari luar wilayah tersebut. Sependapat dengan penjelasan menguraikan bahwa masyarakat Sasak merupakan masyarakat religius yang taat menjalankan ajaran agama Islam. Namun pada hari-hari tertentu juga melaksanakan ziarah makam dan tradisi berkaul terutama pada makam-makam yang dianggap keramat. Tradisi ziarah makam dan berkaul tetap berkembang sampai saat ini karena merupakan ajaran yang bersifat mubah (dibolehkan) dalam pandangan Agama Islam[15].

Jadi perubahan gaya hidup yang di ungkapkan oleh informan menunjukkan pergeseran gaya hidup dalam masyarakat khususnya masyarakat Desa Batu Layar. Wisatawan yang sering berkunjung ke Desa Batu Layar dengan budaya mereka yang berbeda-beda. Perubahan Gaya hidup seperti gaya berpakaian yang mini, minum minuman yang beralkohol. Sejalan dengan hasil penelitian yang menjelaskan bahwa modernisasi dan perubahan sosial merupakan dua hal yang saling berkaitan. Modernisasi pada hakikatnya mencakup bidang-bidang yang sangat banyak, bidang mana yang akan diutamakan oleh suatu masyarakat tergantung dari kebijakan penguasa yang memimpin masyarakat tersebut. Modernisasi hampir pasti pada awalnya akan mengalami disorganisasi dalam masyarakat, apalagi 
yang menyangkut nilai-nilai dan norma-norma dalam masyarakat, dimana masyarakat yang bersangkutan belum siap untuk berubah, karena perubahannya begitu cepat serta tidak mengenal istirahat[16]. Jadi pergeseran perlaku manusia dipengaruh lingkungan.

\section{E. SIMPULAN DAN SARAN}

Dampak pariwisata di Desa Batu Layar Kecamatan Batu Layar Kabupaten Lombok Barat pada umumnya telah dilengkapi dengan sarana dan prasarana yang cukup memadai untuk sebuah kawasan wisata. Fasilitasfasilitas pendukung yang dapat ditemui seperti jasa akomodasi (hotel, villa, restoran, café). Sedangkan sarana lain yang menunjang seperti alat transportasi, akses jalan yang mudah, listrik, air, perbankan, puskesmas dan lain sebaginya.

Masyarakat Desa Batu Layar Kecamatan Batu Layar telah mengalami pergeseran dalam struktur sosial masyarakat (struktural) dan pergeseran dalam struktur kebudayaan (kultural). Dalam hal pergeseran struktural terjadi perubahan jenis pekerjaan dari petani dan nelayan menjadi beralih profesi sebagai pedagang, karyawan hotel, café, bar, restoran dan lain sebagainya. Dalam hal pergeseran kultural telah terjadi perubahan gaya hidup dan cara berpakaian yang sebelumnya masyarakat Desa Batu Layar memakai pakaian tradisional dan sekarang memakai gaya berpakaian mini dan modern. Oleh karena itu, agar tidak terjadi kemerosotan moral anak maka yang perlukan dilakukan adalah meningkatkan pendidikan karakter di kawasan pariwisata, karena pendidikan karakter sangatlah penting untuk membentuk kepribadian anak, hal ini sesuai hasil penelitian menjelaskan bahwa pendidikan karakter yang dimilki anak yakni karakter religius, jujur, toleransi, peduli sosial, tanggung jawab, peduli lingkungan, bersahabat dan demokratis. Nilai karakter tersebut sebagai penopang peningkatan karakter anak dalam menghadapi globalisasi[17].

Dengan demikian disarankan bahwa hendaknya masyarakat Desa Batu Layar dan pemerintah terkait, lebih memperhatikan semua fasilitas-fasilitas pariwisata yang ada dengan memelihara dan mengawasi jalannya aktifitas kepariwisataan baik menyangkut objek wisata maupun wisatawan yang datang berkunjung, bertanggung jawab terhadap semua fasilitas pariwisata yang menjadi aset daerah. Kemudian juga sebagai masyarakat yang berada di kawasan wisata tentunya tidak terlepas dari fenomena-fenomena yang ada dan mengakibatkan terjadinya pergeseran baik pergeseran dalam strutur sosial masyarakat (struktural) maupun pergeseran dalam struktur kebudayaan (kultural). Oleh sebab itu sebaiknya masyarakat harus mampu beradaptasi dan menerima setiap kebudayaan yang datang, baik dibawa oleh wisatawan asing maupun domestik yang berkunjng ke Desa Batu Layar.

\section{UCAPAN TERIMA KASIH}

Penulis mengucapkan terima kasih kepada Universitas Muhammadiyah Mataram yang senantiasa memberikan dukunga materi dan moral dan masukan kepada penulis sehingga artikel ilimiah ini selesai dengan baik.

\section{DAFTAR RUJUKAN}

[1] M. M. P. M. K. Batulayar and K. L. Barat, "Pemberdayaan Ekonomi Umat Islam," J. Penelit. Keislam., vol. 4, no. 1, pp. 85-98, 2007.

[2] I. G. Pitana and I. K. S. Diarta, "Pengantar Ilmu Pariwisata," Yogyakarta Andi, 2009.

[3] I. G. B. R. Utama, Pemasaran Pariwisata. Penerbit Andi, 2017.

[4] I. G. Pitana and P. G. Gayatri, Sosiologi Pariwisata: Kajian Sosiologis terhadap Struktur, Sistem, dan Dampak-dampak Pariwisata. Andi, 2005.

[5] O. A. Yoety, Ekonomi pariwisata: introduksi, informasi, dan aplikasi. Penerbit Buku Kompas, 2008.

[6] G. R. Dantes, K. Sudarma, and H. Suputra, "Virtual Reality dan Augmented Reality: Pemberdayaan Wisata Bawah Laut dalam Rangka Meningkatkan Daya Dukung Pariwisata," Proceeding Semnasvoktek, vol. 1, p. 8, 2016.

[7] M. L. Suryadana, Sosiologi Pariwisata: Kajian Kepariwisataan dalam Paradigma IntergratifTransformatif menuju Wisata Spiritual. Humaniora, 2017.

[8] B. D. Suwandi and M. Si, "Memahami Penelitian Kualitatif Jakarta: PT," Reneka Cipta, 2008.

[9] A. Suharsimi, "Prosedur penelitian suatu pendekatan praktik," Jakarta: Rineka Cipta, 2006.

[10] Sugiyono, "Metode Penelitian kuantitatif kualitatif dan R dan D," Alf. Bandung, 2010.

[11] M. B. Miles and A. M. Huberman, Analisis Data Kualitatif. Terjemahan Tjetjep Rohendi Rohidi. 1992.

[12] W. Hernawan, "Pengaruh Media Massa Terhadap Perubahan Sosial Budaya Dan Modernisasi Dalam Pembangunan," Kom Realitas Sos. J. Ilmu Komun., vol. 4, no. 4, 2012.

[13] P. P. P. A. Nasution, R. P. Rangkuty, A. Ketaren, and R. Faisal, "Modul Praktik Kerja Lapangan," 2016.

[14] H. Adrian and W. Resmini, "Pengaruh Globalisasi Terhadap Nilai-Nilai Budaya pada Rumah Tradisional Masyarakat Sade Lombok Tengah," Civ. Pendidikan-Penelitian-Pengabdian Pendidik Pancasila dan Kewarganegaraan, vol. 6, no. 2, pp. 13-22, 2018.

[15] I. G. A. Armini, "Tradisi Ziarah Dan Berkaul Pada Makam Keramat Di Lombok Nusa Tenggara Barat," J. Penelit. Sej. dan Nilai Tradis., vol. 23, no. 1, pp. 81-100, 2017.

[16] E. Rosana, "Modernisasi dan perubahan sosial," $J$. TAPIs, vol. 7, no. 1, pp. 46-62, 2011.

[17] F. Fitriani and A. Sakban, "Penerapan Pendidikan Karakter Terhadap Efektifitas Penggunaan Kurikulum 2013 Dalam Persepektif Moral Bangsa di SMA Nurul Jannah NW Ampenan," Civ. 
58 CIVICUS : Pendidikan-Penelitian-Pengabdian Pendidikan Pancasila dan Kewarganegaraan | Vol. 7, No. 2, September 2019, hal 48 - 58

Pendidikan-Penelitian-Pengabdian Pendidik.

Pancasila dan Kewarganegaraan, vol. 6, no. 1,

pp. 1-7, 2018. 